\title{
Questes
}

Revue pluridisciplinaire d'études médiévales

\section{Ruches, ruchers et récoltes de miel et de cire}

\section{Catherine Mousinho}

\section{(2) OpenEdition \\ Journals}

\section{Édition électronique}

URL : http://journals.openedition.org/questes/4167

DOI : 10.4000/questes.4167

ISSN : 2109-9472

\section{Éditeur}

Les Amis de Questes

\section{Édition imprimée}

Date de publication : 15 septembre 2008

Pagination : 19-38

ISSN : 2102-7188

\section{Référence électronique}

Catherine Mousinho, «Ruches, ruchers et récoltes de miel et de cire », Questes [En ligne], 15 | 2008,

mis en ligne le 01 janvier 2014, consulté le 23 avril 2019. URL : http://journals.openedition.org/ questes/4167 ; DOI : 10.4000/questes.4167

Ce document a été généré automatiquement le 23 avril 2019.

(c) Association des amis de « Questes » 


\section{Ruches, ruchers et récoltes de miel et de cire}

Catherine Mousinho

NOTE DE L'ÉDITEUR

Cet article n'a pas encore fait l'objet d'une autorisation de publication. 